УДК 619:636.1:591.111

М. В. Луценко, аспірант

М. П. Петрушко, к.с.-Г.н., доцент

Харківська державна зооветеринарна академія, кафедра технології тваринництва ім. ак. М. Д. Потьомкіна, вул. Академічна, 1, смт Мала Данилівка, Дергачівський р-н, Харківська обл., 62341, Україна,0968180679, e-mail: m.lucenko21@mail.ru

\title{
ВПЛИВ ФІЗИЧНОГО НАВАНТАЖЕННЯ НА ДИНАМІКУ ПОКАЗНИКІВ КРОВІ КОНЕЙ РІЗНОГО ВІКУ
}

Представлено аналіз динаміки клінічних та біохімічних показників крові коней різних вікових груп під впливом фізичного навантаження різноманітної інтенсивності та спрямованості. Визначено загальний стан, ємність аеробних $\mathrm{i}$ анаеробних систем енергозабезпечення та витривалість коней різного віку на кінець змагального періоду за показниками крові.

Ключові слова: коні, вік, показники крові, фізичне навантаження.

Кінний спорт користується великою популярністю, але вимагає великих витрат на утримання та підготовку коня. Тому зберегти його працездатність, продовжити спортивне довголіття вважається пріоритетним завданням для кожного кіннотника [1]. Велика кількість спортивних змагань і пов'язані $з$ цим часті перевезення чинять на коня підвищені фізичні та емоційні навантаження, у зв'язку з чим ускладнюється підтримка гарного стану його здоров 'я та тренованості [2].

Нині, коли вимоги до спортивних коней нестримно зростають, їх організм не завжди в змозі переносити пропоновану інтенсивність тренувальних навантажень [5]. При цьому найчастіше порушується діяльність серцево-судинної та опорно-рухової системи, нервово-рефлекторні механізми координації рухів та ін. Головною причиною зниження адаптаційного потенціалу організму коня $\epsilon$ невідповідність між тривалістю відновлювального періоду і мірою зрушень в організмі, спричинених фізичними навантаженнями [4].

Найбільш розповсюдженими способами оцінки фізичного стану та тренованості коня є візуальна оцінка поведінки, врахування частоти пульсу та дихання і швидкості їх нормалізації після фізичного навантаження. Проте жоден 3 цих методів не дає повної інформації про стан коня. Одним із перспективних напрямів $\epsilon$ оцінка функціональних можливостей організму коня на основі реєстрації змін складу крові, що дозволяє оцінити його адаптаційний потенціал. Клінічні та біохімічні дослідження крові в процесі тренінгу допомагають у вирішенні питань фізичного стану працюючих коней, визначенні їх потенційних можливостей, регулюванні фізичних навантажень [9]. 


\section{Матеріали і методи дослідження}

Дослідження проведені на 17 головах коней різного віку Дергачівської дитячо-юнацької кінноспортивної школи при Харківській державній зооветеринарній академії (ДДЮКСШ при ХДЗВА) з серпня по вересень 2014 року (кінець змагального періоду). У коней проводили забір крові з яремної вени у стані відносного спокою, відразу після фізичного навантаження $(\Phi / H)$ і через 2 години після навантаження.

Дослідження крові проводилися на базі лабораторії Харківської міської клінічної багатопрофільної лікарні № 17. Визначення клінічних показників проводилося у цільній крові, біохімічних - у сироватці крові.

Клінічні показники крові: швидкість осідання еритроцитів (ШОЕ) визначали за методом Панченкова; кількість еритроцитів, лейкоцитів та тромбоцитів підраховували під мікроскопом у камері Горяєва; лейкоцитарну формулу визначали методом мікроскопії мазку крові, забарвленого за РомановськимГімза; концентрацію гемоглобіну визначали гемоглобінціанідним методом; середній вміст гемоглобіну в одному еритроциті розраховували за формулою; гематокрит визначали за методом Уінтроба.

Біохімічні показники крові визначали за набором BioSystems (Італія) за інструкцією і контролем виробника, рівень лактату та пірувату в крові - ензиматичним методом з використанням лактатдегідрогенази; у сироватці крові визначали ферменти (АлАТ, АсАТ, лужна фосфатаза, $\gamma$-глутамінтранспептидаза, ЛДГ), загальний білок, а також показники азотистого (сечовина, креатинін, сечова кислота), вуглеводного (глюкоза, лактат, піруват), ліпідного (тригліцериди, холестерин), пігментного (білірубін загальний, прямий та непрямий) та мінерального (залізо, кальцій) обмінів.

\section{Результати дослідження та їх обговорення}

Для проведення досліду коні були розділені на групи в залежності від віку: молодша група (6-7 років) $(\mathrm{n}=4)$, середня група (8-15 років) $(\mathrm{n}=4)$ і старша група (16-20 років) $(\mathrm{n}=9)$.

Встановлено, що загалом клінічні показники крові усіх вікових груп знаходяться у межах фізіологічної норми [6]. Проте між групами спостерігаються значні відмінності (табл. 1). Найвищі показники ШОЕ, кількості гемоглобіну та еритроцитів спостерігаються у крові коней молодшої вікової групи. Це вказує на високу кисневу ємність крові та інтенсивне протікання аеробних окислювальних реакцій [4]. У крові коней середньої та старшої вікової групи спостерігається зниження концентрації еритроцитів після фізичного навантаження. Причиною цього може бути їх механічний гемоліз унаслідок інтенсивного фізичного навантаження. Через 2 години після навантаження у коней цієї групи відбувається різке збільшення концентрації еритроцитів внаслідок згущення крові і виходу цих формених елементів із депо. 
䀂

\begin{tabular}{|c|c|c|c|c|c|c|c|c|c|c|c|c|c|}
\hline \multirow{3}{*}{ 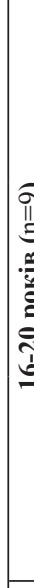 } & 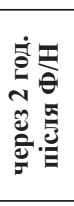 & 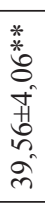 & 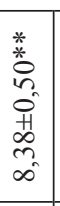 & 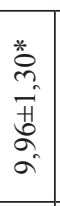 & 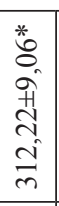 & $\begin{array}{l}\tilde{O}_{0} \\
\text { 音 } \\
=\end{array}$ & 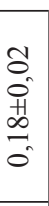 & 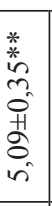 & 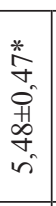 & 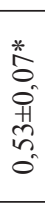 & 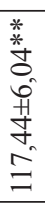 & 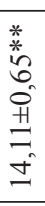 & 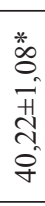 \\
\hline & 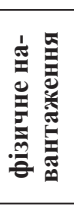 & 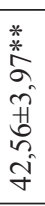 & 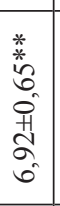 & 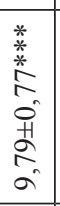 & 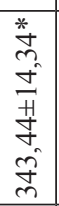 & $\begin{array}{l}\tilde{\delta} \\
\text { 辛 } \\
\text { ?. }\end{array}$ & $\begin{array}{l}\stackrel{*}{0} \\
0 \\
0 \\
0 \\
0 \\
0 \\
0 \\
0\end{array}$ & 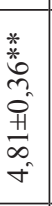 & $\begin{array}{l}\stackrel{*}{\%} \\
\text { o } \\
\text { Oे } \\
\stackrel{+}{=} \\
\dot{f}\end{array}$ & 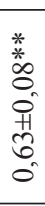 & 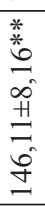 & 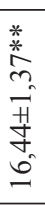 & $\begin{array}{l}\frac{*}{0} \\
- \\
\vec{H} \\
\vec{f}\end{array}$ \\
\hline & 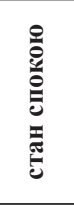 & 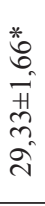 & 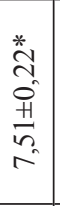 & 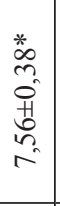 & 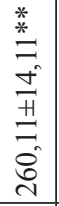 & $\begin{array}{l}\overrightarrow{0} \\
0 \\
0 \\
0 \\
0\end{array}$ & 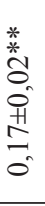 & 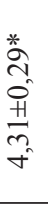 & 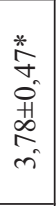 & 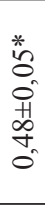 & 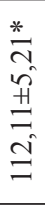 & 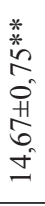 & 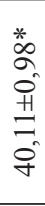 \\
\hline & 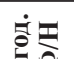 & f & $\vec{\sigma}$ & $\infty$ & $\vec{m}$ & 0 & ஓ & $=$ & $\approx$ & 으. & f & & \\
\hline
\end{tabular}

\begin{tabular}{|c|c|c|c|c|c|c|c|c|c|c|c|c|c|c|c|c|}
\hline & 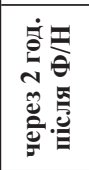 & 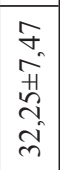 & $\begin{array}{l}\vec{a} \\
0 \\
m \\
m \\
\stackrel{m}{r}\end{array}$ & $\begin{array}{l}\infty \\
\vec{H} \\
\tilde{H} \\
\infty\end{array}$ & 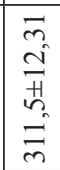 & ' & $\begin{array}{l}8 \\
8 \\
0 \\
+1 \\
0 \\
0\end{array}$ & ' & & $\begin{array}{l}8 \\
0 \\
0 \\
\text { 1 } \\
0\end{array}$ & 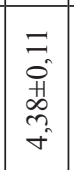 & $\begin{array}{c}2 \\
0 \\
0 \\
0 \\
0 \\
i n\end{array}$ & $\begin{array}{l}0 \\
0 \\
0 \\
0 \\
0 \\
0 \\
0 \\
0\end{array}$ & 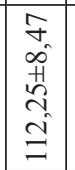 & $\begin{array}{l}\vec{F} \\
\text { Oे } \\
\text { 莳 }\end{array}$ & $\begin{array}{l}n \\
\tilde{n} \\
\tilde{i} \\
\tilde{n} \\
\tilde{n}\end{array}$ \\
\hline \multirow{2}{*}{ 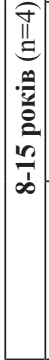 } & 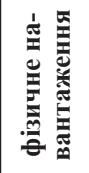 & $\begin{array}{l}\vec{N} \\
\text { in } \\
\stackrel{4}{n} \\
\dot{m}\end{array}$ & $\begin{array}{l}\infty \\
1 \\
0 \\
0 \\
0 \\
0 \\
0\end{array}$ & $\begin{array}{l}\vec{F} \\
0 \\
\hat{+} \\
\overrightarrow{0}\end{array}$ & 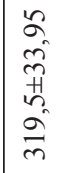 & ' & $\begin{array}{l}8 \\
0 \\
0 \\
0 \\
0\end{array}$ & ' & & $\begin{array}{l}0 \\
0 \\
0 \\
0 \\
0 \\
0 \\
0\end{array}$ & $\mid \begin{array}{l}\tilde{N} \\
\tilde{0} \\
\hat{H} \\
\alpha \\
\tilde{m}\end{array}$ & $\begin{array}{l}\vec{t} \\
0 \\
0 \\
\hat{1} \\
i\end{array}$ & 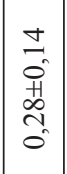 & 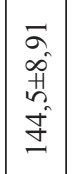 & $\begin{array}{l}\tilde{\sigma} \\
\vec{H} \\
\stackrel{H}{\approx} \\
\dot{\Xi}\end{array}$ & $\begin{array}{l}\text { tे } \\
\text { i } \\
\text { H } \\
\text { in } \\
\text { f }\end{array}$ \\
\hline & 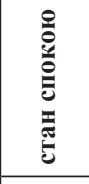 & $\begin{array}{l}\tilde{N} \\
\tilde{y} \\
\tilde{H} \\
\tilde{m} \\
\tilde{d}\end{array}$ & 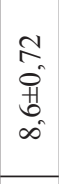 & $\begin{array}{l}n \\
\alpha \\
i \\
\hat{n} \\
\alpha \\
\alpha\end{array}$ & 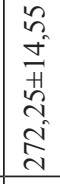 & ' & $\begin{array}{l}8 \\
0 \\
0 \\
1 \\
0 \\
0\end{array}$ & ' & & $\begin{array}{l}0 \\
0 \\
0 \\
m \\
0 \\
0\end{array}$ & 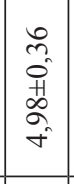 & 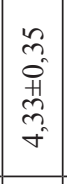 & $\begin{array}{l}0 \\
8 \\
0 \\
0 \\
0 \\
0 \\
0\end{array}$ & 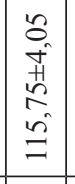 & 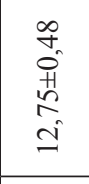 & 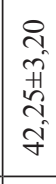 \\
\hline & 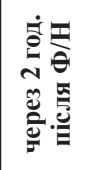 & $\begin{array}{l}* \\
0 \\
\infty \\
00 \\
01 \\
0 \\
\tilde{n}\end{array}$ & 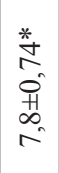 & 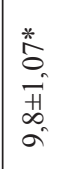 & 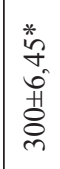 & ' & $\begin{array}{l}8 \\
0 \\
0 \\
1 \\
0 \\
0\end{array}$ & ' & ' & $\begin{array}{l}0 \\
0 \\
0 \\
0 \\
0 \\
0\end{array}$ & $\begin{array}{c}* \\
0 \\
0 \\
0 \\
11 \\
\infty \\
\infty \\
0\end{array}$ & $\begin{array}{c}* \\
0 \\
0 \\
0 \\
+1 \\
\text { in } \\
\text { in }\end{array}$ & $\mid \begin{array}{l}* \\
\tilde{o} \\
0 \\
0 \\
\hat{n} \\
\hat{n} \\
0\end{array}$ & 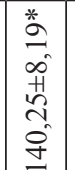 & $\begin{array}{l}* \\
0 \\
0 \\
0 \\
0 \\
n \\
i \\
\text { in }\end{array}$ & 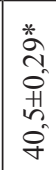 \\
\hline \multirow[t]{2}{*}{ 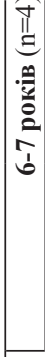 } & 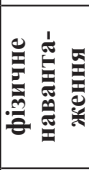 & 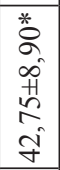 & 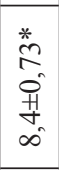 & 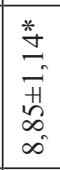 & \begin{tabular}{|l|}
\multirow{2}{*}{} \\
$\vec{\sigma}$ \\
$\dot{n}$ \\
$\vec{H}$ \\
$\tilde{n}$ \\
$\tilde{m}$ \\
\end{tabular} & ' & $\begin{array}{l}0 \\
0 \\
0 \\
0 \\
0 \\
0\end{array}$ & ' & ' & $\begin{array}{c}* \\
\tilde{0} \\
0 \\
0 \\
\infty \\
0 \\
0 \\
0\end{array}$ & 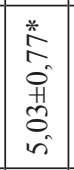 & \begin{tabular}{|l|}
$*$ \\
\\
0 \\
0 \\
0 \\
00 \\
$o$ \\
$\dot{\sigma}$ \\
\end{tabular} & \begin{tabular}{|l|}
$*$ \\
0 \\
00 \\
0 \\
0 \\
0 \\
0 \\
0 \\
\end{tabular} & 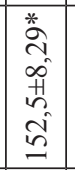 & 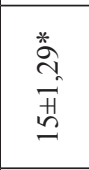 & 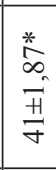 \\
\hline & 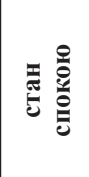 & 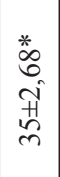 & 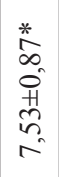 & 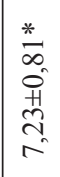 & 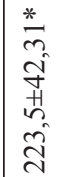 & ' & $\begin{array}{l}8 \\
0 \\
0 \\
\text { 1 } \\
0 \\
0\end{array}$ & ' & ' & $\begin{array}{l}* \\
\tilde{0} \\
0 \\
0 \\
0 \\
0 \\
0\end{array}$ & 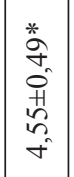 & $\mid \begin{array}{l}* \\
0 \\
0 \\
0 \\
0 \\
0 \\
0 \\
+ \\
+\end{array}$ & 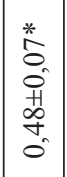 & 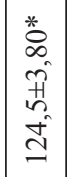 & 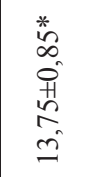 & 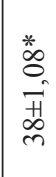 \\
\hline & 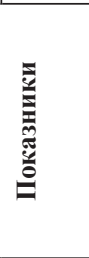 & 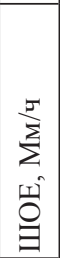 & 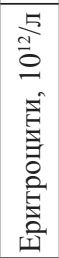 & 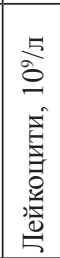 & 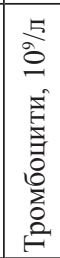 & 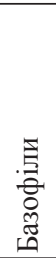 & 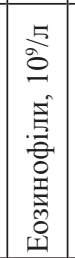 & 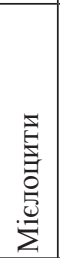 & & 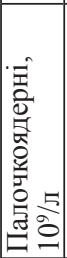 & 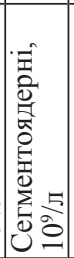 & 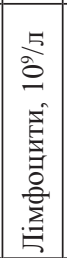 & 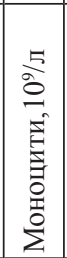 & 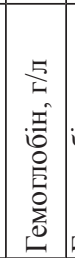 & 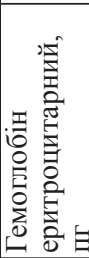 & 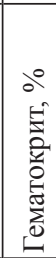 \\
\hline
\end{tabular}


Ріст концентрації лейкоцитів через 2 години після фізичного навантаження, що спостерігається у коней молодшої та старшої вікової групи, частково може пояснюватися травмою тканин (частіше за все м язової), що підтверджується ростом лімфоцитів, які приймають участь у знешкодженні тканинних метаболітів.

Збільшення кількості нейтрофілоцитів із зрушенням вліво, зменшення кількості лімфоцитів і эозинофілоцитів у крові коней середньої вікової групи $\epsilon$ ознакою настання у них 2-ої (нейтрофільної) фази міогенного лейкоцитозу в результаті напруженої фізичної роботи (за А. П. Сгоровим (1926)).

У коней молодшої та старшої вікової групи внаслідок $\Phi / Н$ спостерігається збільшення концентрації нейтрофілоцитів, лімфоцитів і особливо моноцитів (характерні ознаки протікання запального процесу в організмі), що в даному випадку може бути наслідком різкого підвищення температури тіла під впливом фізичного навантаження. У коней молодшого віку це явище можна пояснити недостатнім розвитком загальної витривалості та тренованості, а у коней старшого віку - повільним протіканням відновлювальних процесів в організмі.

Аналізуючи біохімічні показники крові, можна відмітити, що у коней усіх вікових груп у стані спокою спостерігається підвищена активність АсAT, що говорить про напруженість у роботі серцевого м язу (табл. 2). Дуже висока активність $\gamma$-ГГТ, що більш ніж у два рази перевищує норму, може свідчити про певні порушення у роботі печінки. Знижений рівень сечової кислоти, що утворюється при розпаді пуринових основ, пояснюється низьким вмістом пуринів у згодовуваному кормі.

Фізичне навантаження по різному впливає на досліджувані показники у коней різного віку.

У середній віковій групі спостерігається зниження активності лужної фосфатази внаслідок анаеробної направленості фізичних навантажень [3]. Натомість у молодшої вікової групи спостерігається підвищення цього показнику, що може свідчити про напруженість у роботі фізіологічних систем організму і в першу чергу опорно-рухового апарату [8].

У середній - внаслідок інтенсивної фізичної роботи спостерігається зниження рівня сечовини після $\Phi / Н$ через невідповідність між швидкістю відновлювальних процесів і мірою зрушень в організмі, спричинених фізичними навантаженнями [7].

Найбільша концентрація креатиніну спостерігається у сироватці крові коней середньої та старшої вікових груп, що свідчить про активне підключення креатинфосфокіназного механізму енергозабезпечення при виконанні $\Phi / \mathrm{H}$.

В усіх групах коней після фізичного навантаження знижується концентрація заліза у сироватці крові через його використання на побудову зруйнованих під час $\Phi / Н$ еритроцитів. 
질

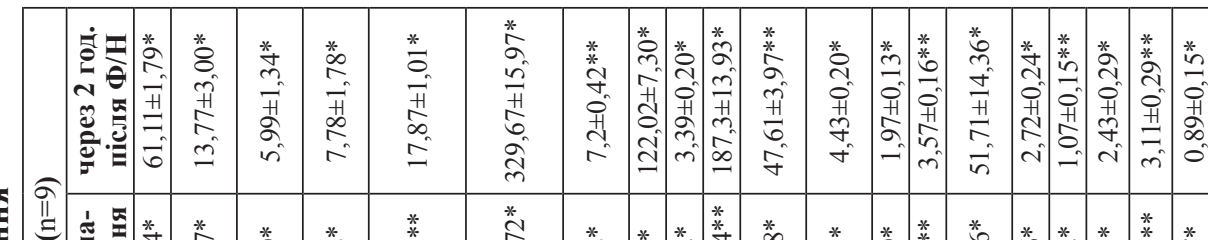

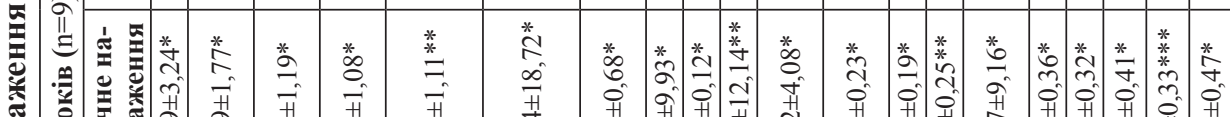

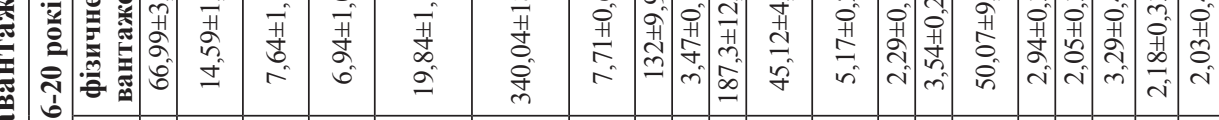

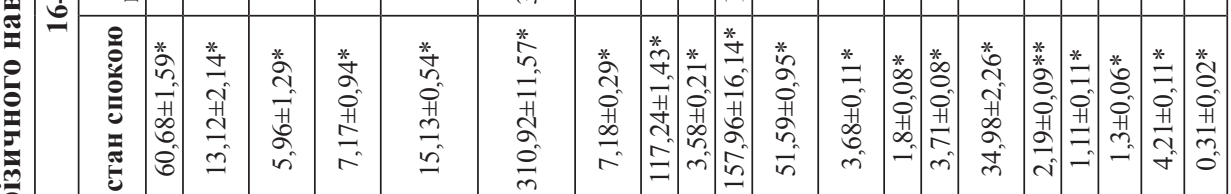

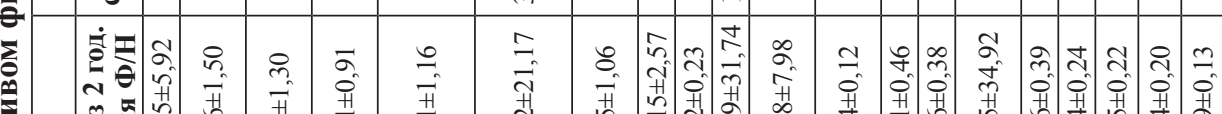

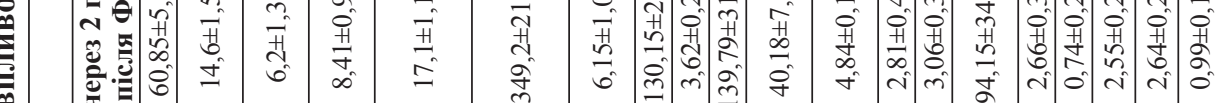

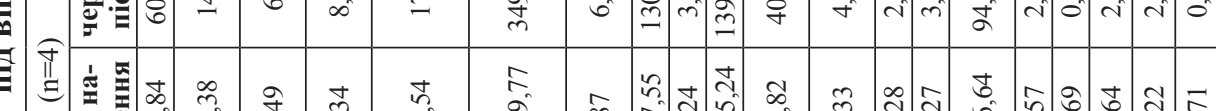

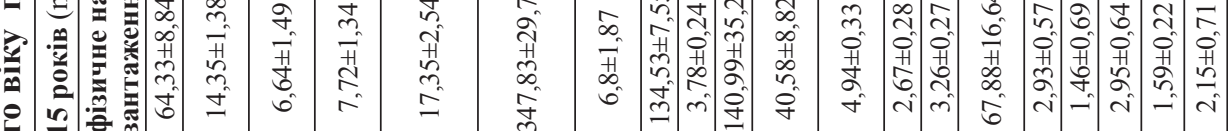

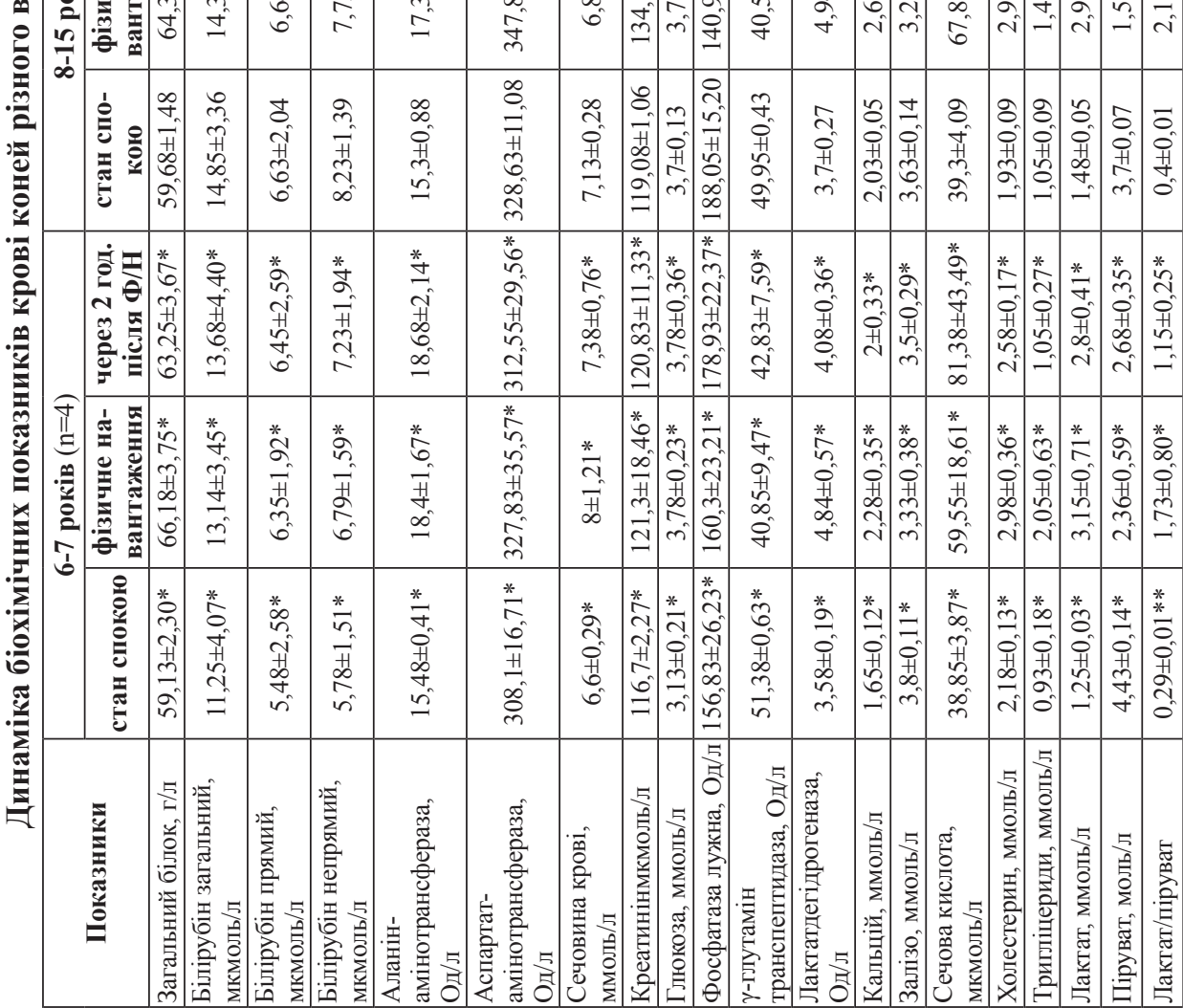


Рівень сечової кислоти в усіх групах коней через 2 години після навантаження продовжує зростати, що пояснюється інтенсивним розпадом нуклеїнових кислот.

У коней середньої вікової групи зниження рівня тригліцеридів нижче норми через 2 години після фізичної роботи може свідчити про використання організмом жирних кислот як джерела енергії через вичерпання вуглеводних запасів, що підтверджується падінням рівня глюкози через 2 години після $\Phi / \mathrm{H}$.

У коней старшої вікової групи спостерігається найбільше зростання концентрації лактату у сироватці крові i, відповідно найвища каталітична активність ЛДГ. Високий рівень лактату після фізичного навантаження говорить про підключення анаеробного лактатного механізму енергозабезпечення внаслідок вичерпання енергетичних ресурсів організму, про що свідчить і падіння рівня глюкози через 2 години після $\Phi / \mathrm{H}$.

\section{Висновки}

1. Клінічні показники крові коней усіх вікових груп знаходяться у межах фізіологічної норми. Проте між групами спостерігаються значні відмінності.

2. У коней усіх вікових груп у стані спокою спостерігаються відхилення активності АсАТ, $\gamma$-ГГТ та рівня сечової кислоти від норми, що може пояснюватися загальною втомою організму наприкінці змагального періоду та певними недоліками раціону.

3. Організм коней молодшої вікової групи характеризуються найбільшою інтенсивністю протікання аеробних окислювальних реакцій, що підтверджується найвищими показниками ШОЕ, кількості гемоглобіну та еритроцитів.

4. Коні середньої та старшої вікових груп володіють найбільшою ємністю анаеробного креатинфосфокіназного механізму енергозабезпечення, про що свідчить найбільша концентрація креатиніну у сироватці крові, вони же несуть найбільш інтенсивні фізичні навантаження анаеробного характеру, що підтверджується зниженням рівня сечовини та лужної фосфатази, ознаками настання нейтрофільної фази міогенного лейкоцитозу та вичерпанням вуглеводних запасів організму.

5. У коней старшої вікової групи внаслідок Ф/Н відбувається вичерпання енергетичних ресурсів організму, що відображається у зростанні концентрації лактату, високій каталітичній активності ЛДГ і падінні рівня глюкози.

6. У коней молодшої та старшої вікових груп $Ф / Н$ викликає напруженість у роботі опорно-рухового апарату, що підтверджується ростом концентрації лімфоцитів та підвищенням активності лужної фосфатази. 


\section{Список використаної літератури}

1. Бородкина Е. Ю. Показатели крови племенных и спортивных лошадей в связи с функциональным состоянием: диссертация на соискание ученой степени кандидата биологических наук: 03.00.13 / Бородкина Елена Юрьевна. - Рязань, 2008.

2. Горбунова Н. Д. Влияние недопинговой микроэлементной добавки на восстановление спортивных лошадей после интенсивных физических нагрузок: диссертация на соиск. ученой степени канд. биологических наук: 03.00.13 / Горбунова Наталия Дмитриевна. - Рязань, 2009. - 95 с.

3. Губернаторов Н. А. Влияние мышечных нагрузок на морфологические и цитохимические показатели крови: диссертация на соиск. ученой степени канд. биологических наук: 14.00.17 / Губернаторов Николай Алексеевич. - Ленинград, 1984. - 195 с.

4. Мансурова Л. Р. Влияние возраста и физической нагрузки на адаптационные ресурсы организма лошадей: диссертации на соискание ученой степени кандидата биологических наук: 03.00.13 / Мансурова Лилия Робертовна. - Троицк, 2009.

5. Полозков А. И. Влияние тренинга в среднегорье и препаратов аутогенной крови на функциональное состояние и работоспособность быстроаллюрных лошадей: диссертация на соиск. ученой степени канд. биологических наук: 03.00.13 / Полозков Александр Иванович. - ВННИК, 1985. - 166 с.

6. Практикум по биохимии: Учеб. Пособие / Под ред. С. Е. Северина, Г. А. Соловьевой. - 2-е изд., перераб. и доп. - Москва: Изд-во МГУ, 1989. - 509 с.

7. Сейранов С. Г. Контроль за физическими нагрузками по мочевине / С. Г. Сейранов, М. И. Шикунов // Лыжный спорт: [сб.]. - Москва, 1986. - Вып. 1. - С. 19-23.

8. Сергиенко Г. Ф. Физиологические и биохимические аспекты тренинга быстроаллюрных лошадей: автореф. дис. на соиск. уч. ст. докт. биол. наук / Г. Ф. Сергиенко. - Дубовицы: ВНИИК, 1998. - 36 с.

9. Тхинвалели Г. Г. Использование биодинамических, биохимических и генетических показателей в совершенствовании хозяйственно-полезных качеств лошадей русской верховой породы: диссертация на соиск. ученой степени канд. биологических наук: 06.02.10 / Тхинвалели Георгий Гарриевич. - Москва, 2011. - $111 \mathrm{c}$

Стаття надійшла до редакції 20.02.2015

\section{М. В. Луценко, Н. П. Петрушко}

Харьковская государственная зооветеринарная академия, кафедра технологии животноводства им. ак. М. Д. Потемкина, ул. Академическая, 1, смт Малая Даниловка, Дергачовский р-н, арьковская обл., 62341, Украина

\section{ДИНАМИКА ПОКАЗАТЕЛЕЙ КРОВИ ЛОШАДЕЙ РАЗНОГО ВОЗРАСТА ПОД ВОЗДЕЙСТВИЕМ ФИЗИЧЕСКОЙ НАГРУЗКИ}

Резюме

Представлен анализ динамики клинических и биохимических показателей крови лошадей разных возрастных групп под воздействием физической нагрузки разнообразной интенсивности и направленности. Определено общее состояние, емкость аэробных и анаэробных систем энергообеспечения и выносливость лошадей разного возраста на конец соревнований по показателям крови.

Ключевые слова: лошади, показатели крови, физическая нагрузка, возраст. 
M. V. Lutsenko, N. P. Petrushko

Kharkov state zooveterinary academy,

department of Animal Technology after academician M. D. Potemkyn,

1, Akademicheskay Str., smt Malaya Danilovka, Dergachovskiy district,

Kharkov region, 62341, Ukraine

\title{
BLOOD INDICES DYNAMICS OF HORSE OF DIFFERENT AGE UNDER THE ACT OF PHYSICAL ACTIVITY
}

\begin{abstract}
Summary
Researches and analysis of blood clinical and biochemical parameters dynamics of horses of the different age groups under the act of physical activity of various intensity and orientation have been carried out in this work. The common state, capacity of the aerobic and anaerobic power supply systems and endurance of different age horses ' organism have been determined on the end of competition period on the basis of investigated blood parameters.
\end{abstract}

Key words: horses, blood, parameters, physical activity, age. 